\title{
Effect of the farming system and postharvest frozen storage on quality attributes of two strawberry cultivars
}

\author{
Giancarlo Barbieri, Emma Colonna, Youssef Rouphael` and Stefania De Pascale \\ Department of Agricultural Sciences, University of Naples Federico II, 80055 Portici, Italy
}

Received 1 April 2015 - Accepted 28 July 2015

\begin{abstract}
Introduction. Consumer interest in organic fruit is increasing based on the assumption that these products are healthier, despite a lack of conclusive evidence. Strawberry (Fragaria $\times$ ananassa Duch.) is a rich source of antioxidants and an important fruit in the human diet. Materials and methods. The configuration of strawberry fruit quality was analyzed in a factorial approach accounting for the effects of the farming system and postharvest frozen storage. The strawberry cultivars 'Sabrina' and 'Ventana' grown under organic and conventional farming management were stored postharvest at $-40{ }^{\circ} \mathrm{C}$ for 6 months. Fruits obtained under the two farming systems were analyzed fresh after harvest and thawed after frozen storage. Fruit quality was evaluated in terms of physical, chemical and phytochemical properties. Results and discussion. The surface lightness, firmness, lipophilic antioxidant activity, soluble solids, ascorbic acid and ellagic acid contents were significantly higher at harvest than after thawing. Frozen storage increased only hydrophilic antioxidant activity, leaving reducing sugars and total phenols without significant alterations. The color of organic fruits in both cultivars was brighter and more vivid (higher $\mathrm{L}^{*}$ and $\mathrm{C}^{*}$ values). Farming management did not

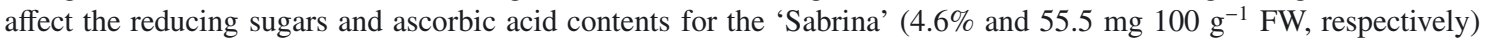
or 'Ventana' (4.0\% and $31.2 \mathrm{mg} 100 \mathrm{~g}^{-1} \mathrm{FW}$, respectively) cultivars. The organic 'Ventana' strawberry had higher soluble solid content and hydrophilic antioxidant activity, whereas an opposite trend was observed in total phenols and ellagic acid contents for 'Ventana' and 'Sabrina', respectively. Conclusion. The quality of strawberries, in particular the bioactive compounds, varied according to the farming system and postharvest frozen storage. The cultivation factors, including the farming management and cultivar, may significantly interact to affect quality attributes of strawberry fruit.
\end{abstract}

Keywords: Italy / strawberry / Fragaria $\times$ ananassa / organic farming / fruit quality / antioxdant activity / ascorbic acid / ellagic acid / phenolics

Résumé - Effet du système de culture et de congélation post-récolte sur les attributs de qualité de deux cultivars de fraisier. Introduction. L'intérêt des consommateurs pour les fruits issus d'agriculture biologique repose de plus en plus sur l'hypothèse selon laquelle ces produits sont meilleurs pour la santé, malgré l'absence de preuves concluantes. La fraise (Fragaria $\times$ ananassa Duch.) est une source abondante d'antioxydants tout en étant un fruit courant en alimentation humaine. Matériel et méthodes. Les composantes de la qualité de la fraise ont été analysées selon une approche factorielle prenant en compte des effets du système de culture et de stockage post-récolte par congélation. Les fruits des cultivars de fraisiers 'Sabrina' et 'Ventana' cultivés en conduite soit biologique soit conventionnelle, ont été stockés à $-40{ }^{\circ} \mathrm{C}$ après la récolte. Les fruits obtenus selon les deux systèmes de culture ont été analysés frais après la récolte et décongelés après 6 mois stockage. La qualité des fruits a été évaluée en termes de propriétés phytochimiques physiques, chimiques, etc. Résultats et discussion. La douceur de surface, la fermeté du fruit, l'activité anti-oxydante lipophile, les solides solubles, les teneurs en acide ascorbique et en acide ellagique étaient significativement plus élevées à la récolte qu'à la décongélation. La congélation a seulement contribué à augmenter l'activité anti-oxydante hydrophile, laissant les teneurs en sucres réducteurs et en phénols totaux sans modifications importantes. Dans le cas des deux cultivars, la couleur des fruits issus d'agriculture biologique était plus lumineuse et plus vive (valeurs de $\mathrm{L}^{*}$ et de $\mathrm{C}^{*}$ supérieures). La gestion biologique de la production n'a pas affecté les teneurs en sucres réducteurs ni en acide ascorbique des culti-

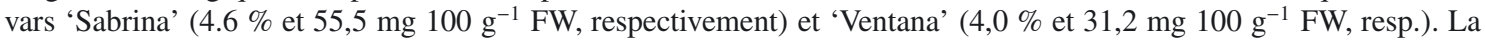
fraise bio 'Ventana' avait un contenu supérieur en solides solubles et une activité anti-oxydante hydrophile plus forte, tandis que la tendance inverse était observée sur les teneurs en phénols totaux et en acide ellagique pour 'Ventana' et 'Sabrina', resp. Conclusion. La qualité des fraises et en particulier les composés bioactifs peuvent varier selon

\footnotetext{
^ Corresponding author: youssef.rouphael@unina.it
} 
le système de culture et le mode de gestion post-récolte. Les facteurs culturaux, y compris la gestion du système d'exploitation et le choix du cultivar, peuvent interagir de façon significative pour affecter les attributs de qualité des fraises.

Mots clés : Italie / fraise / Fragaria $\times$ ananassa / agriculture biologique / qualité du fruit / activité anti-oxydante / acide ascorbique / acide ellagique / composés phénoliques

\section{Introduction}

According to the Codex Alimentarius Commission, "organic agriculture is a holistic production system that promotes health and the sustainable development of agro-ecosystems by obeying biodiversity, biological cycles and soil biological activity using fertilizers of organic origin and renewable energy sources" [1]. The demand for organic products has increased rapidly in the last two decades, partially due to the general perception among consumers that organic foods are healthier and more nutritive than conventionally produced products [2]; although the scientific evidence is still insufficient to confirm or reject this assumption [3].

Strawberry is a major crop in Italy with about 3,700 ha under both open field ( $\sim 700 \mathrm{ha})$ and protected cultivation ( $\sim 3,000 \mathrm{ha})$. The major production areas of strawberry are located in Campania (833 ha), Veneto (633 ha) and Basilicata (509 ha). The Italian strawberry production is almost entirely obtained from conventional farming; however, in the last decade the area devoted to organic strawberry production has doubled from 15 to 34 ha [4]. Strawberry is considered an important fruit in the Mediterranean diet due to its high content of bioactive compounds, in particular antioxidants, which may have relevant biological activity [5]. For instance, strawberries are considered as a relatively potent anti-proliferative agent against the growth of human liver cancer cells HepG2 [6]. Moreover, strawberries are also appreciated by consumers because of their relatively high content of ellagic acid, an antioxidant that has been proposed to exert anticarcinogenic and antimutagenic effects $[7,8]$. Strawberries also contain other antioxidants with health-promoting properties, such as vitamin $\mathrm{C}$, anthocyanins, and other flavonoids such as quercetin and kaempferol $[9,10]$. Concerning the quality parameters of organic strawberry, Olsson et al. [11] demonstrated that strawberry grown organically had a higher ratio of ascorbate to dehydroascorbate and higher total phenolics, ellagic acid and flavonol contents, indicating that organically grown strawberries might have a higher content of secondary metabolites than conventional strawberry. However, other studies [9, 12] reported that organic cultivation had no consistent effects on sugars, antioxidants, and macro- and micronutrients contents in strawberry compared with conventional farming. Therefore, it is premature to conclude that either organic or conventional fruits are healthier. Thus, additional research comparing these two farming management systems is needed to provide further information on this topic [13].

Strawberry is generally consumed as a fresh product or in processed forms, in particular as frozen fruits [14]. The large scale of frozen strawberry production could be associated with the short shelf life of the berries and the very broad scale of the use of frozen fruits in the industrial manufacturing of strawberry jam and juices $[14,15]$. However, during the frozen food chain (freezing, frozen storage and subsequent thawing) strawberries could be subjected to quality changes such as the reduction of the antioxidant compound content [16]. Similarly, Garrote and Bertone [17] demonstrated that strawberry phenolics (i.e. ellagic acid, p-coumaric acid, quercetin and keampferol) are unstable and undergo deterioration during freezing and thawing processes.

Based on the above considerations, the aim of this study was to investigate the effects of the farming system (organic versus conventional) and postharvest treatment (fresh after harvest or thawed after storage for 6 months at $-40{ }^{\circ} \mathrm{C}$ ) on the physical, chemical and phytochemical components of two strawberry cultivars.

\section{Materials and methods}

\subsection{Plant material and sampling}

Two independent experiments were performed to assess the fruit quality of strawberry (Fragaria $\times$ ananassa Duch.) grown under conventional and organic management systems in Vitulazio-Caserta $\left(41^{\circ} 09^{\prime} 46^{\prime \prime} \mathrm{N}\right.$ latitude, $14^{\circ} 12^{\prime} 48^{\prime \prime} \mathrm{E}$ longitude) and in Sezze-Latina (41 $30^{\prime} 33^{\prime \prime} \mathrm{N}$ latitude, $13^{\circ} 04^{\prime} 37^{\prime \prime} \mathrm{E}$ longitude). The 'Sabrina' and 'Ventana' strawberry cultivars were selected as the most representative cultivar used in the province of Caserta (Vitulazio) and Latina (Sezze), respectively. In both experiments, plants were grown in a cold greenhouse on clay soil with drip irrigation. The organic farming was conducted following the EU regulations (EC 834/2007) [18], whereas the conventional farming system was done according to the standard farming management practices.

Treatments were defined by a factorial combination of the two farming systems (conventional or organic), and the two postharvest storage treatments (fresh after harvest or thawed after frozen storage). In both experiments, treatments were arranged in a randomized complete block design with three replicates.

Chemical analyses were performed on a representative sample of strawberry fruits of both cultivars collected from each plot. Fruits were picked at commercial maturity $(>80 \%$ of the fruit surface showing red color) early in the morning and were immediately transferred to the laboratory for further analyses. Fruits were selected based on uniformity of size and the absence of physical damage and fungal infection.

Thirty fruits were sampled from each replicate and the total number of strawberry fruits analyzed in each experiment was 360 . The fruits were water-washed and each sample was subdivided into two sub-samples of 15 fruits. One sub-sample 
was used for analysis of firmness, surface color, titratable acidity, antioxidant activity, soluble solids, total sugars and bioactive compound contents. The other sub-sample was stored at $-40{ }^{\circ} \mathrm{C}$ in a freezer for 6 months for analysis. Thawing was carried out at $8{ }^{\circ} \mathrm{C}$ for $10 \mathrm{~h}$ before analysis.

\subsection{Color measurements}

In both experiments, external color was measured on opposite sides of 15 fruits per experimental unit using a Minolta CR-300 Chroma Meter (Minolta Camera Co. Ltd., Osaka, Japan). The measuring aperture diameter was $8 \mathrm{~mm}$, and the instrument was calibrated with a Minolta standard white reflector plate before sampling the berries. Samples were placed on a white background and single readings were taken with the hand-held unit on the upper surface of each strawberry midway between the apical and basal ends. The CIELAB color space parameters recorded were lightness $\left(\mathrm{L}^{*}\right)$, chroma coordinates $\mathrm{a}^{*}$ and $\mathrm{b}^{*}$, chroma $\left(\mathrm{C}^{*}\right)$, and hue angle $\left(\mathrm{h}^{\circ}\right)$ [19].

\subsection{Physicochemical analysis}

In both experiments, fruit firmness $\left(\mathrm{kg} \mathrm{cm}^{-2}\right)$ was determined by penetration using an Ametek firmness tester (Ametek Hunter Spring Division, Hatfield, PA, USA) fitted with a 6-mm o.d. v-notched tip. On the extract obtained by liquefying and filtering the strawberry fruits, the total soluble solids (TSS) content of the juice was determined using an Atago N1 refractometer (Atago Co. Ltd., Tokyo, Japan) and expressed as ${ }^{\circ}$ Brix at $20^{\circ} \mathrm{C}$. Acidity was determined by potentiometric titration with $0.1 \mathrm{M} \mathrm{NaOH}$ up to $\mathrm{pH} 8.1$ using $10 \mathrm{~mL}$ juice and the results were expressed as percentage of citric acid in the juice. Reducing sugars were determined by reaction of a water-soluble portion of the sample with an excess of standard copper sulfate in alkaline tartrate (Fehling's) solution under controlled conditions of time, temperature, reagent concentration and composition, so that the amount of copper reduced is proportional to the amount of reducing sugars in the sample analyzed. Fruit juice $\mathrm{pH}$ was also determined. Fruits were dried in a forced-air oven at $60{ }^{\circ} \mathrm{C}$ for $72 \mathrm{~h}$ and weighed to determine the fruit dry matter (DM).

\subsection{Hydrophilic and lipophilic antioxidant activities}

Two different radical cation assays were used to determine the antioxidant activity of the hydrophilic (i.e. watersoluble) and lipophilic (i.e. lipo-soluble) fractions, on $0.2 \mathrm{~g}$ of lyophilized samples, extracted by distilled water and methanol, respectively. The hydrophilic antioxidant activity (HAA) was assessed using the N,N-dimethyl-p-phenylenediamine (DMPD) method [20]. The principle of the assay is that in the presence of a suitable oxidant solution DMPD forms a stable and colored radical cation (DMPD $\left.{ }^{+}\right)$. Antioxidant compounds which are able to transfer a hydrogen atom to DMPD $^{+}$ quench the color and produce a discoloration of the solution which is proportional to their amount. The lipophilic antioxidant activity (LAA) was measured using the 2,2'-azinobis 3-ethylbenzothiazoline-6-sulfonic acid (ABTS) method as described by Pellegrini et al. [21]. The principle of the assay is that the inhibitory response of the radical cation is proportional to the antioxidant concentration and the reaction is complete at the time point selected of $2.5 \mathrm{~min}$. The HAA and LAA were determined by UV-Vis spectrophotometry. The absorbance of the solution was measured at 505 and $734 \mathrm{~nm}$, respectively. HAA and LAA were expressed as mmol ascorbic acid (AA) and mmol of Trolox (6-hydroxy-2,5,7,8-tetramethylchroman2-carboxylic acid) per $100 \mathrm{~g}$ fresh weight, respectively [20,22].

\subsection{Total ascorbic acid and phenolic contents}

The total ascorbic acid, defined as ascorbic acid (AsA) and dehydroascorbate (DHA) acid, was assessed by spectrophotometric detection on fruit samples from the two experiments. The assay is based on the reduction of $\mathrm{Fe}^{3+}$ to $\mathrm{Fe}^{2+}$ by AsA and the spectrophotometric detection of $\mathrm{Fe}^{2+}$ complexes with 2,2'-dipyridyl [23]. DHA is reduced to AsA by pre-incubation of the sample with dithiothreitol (DTT). The absorbance of the solution was measured at $525 \mathrm{~nm}$, and data were expressed as $\mathrm{mg}$ ascorbic acid on $100 \mathrm{~g}$ fresh weight.

The total phenolic content was determined in methanol extracts $(1 \mathrm{~g}$ of freeze-dried strawberries were extracted in $20 \mathrm{~mL}$ of $60 \%$ methanol) according to the Folin-Ciocalteu procedure [24] using gallic acid as a standard. A $100-\mu \mathrm{L}$ aliquot of the supernatant was combined with $500 \mu \mathrm{L}$ of Folin-Ciocalteu reagent (Sigma Aldrich Inc., St Louis, MO, USA) and $400 \mu \mathrm{L}$ of $7.5 \%$ sodium carbonate/water (w/v). The tubes were mixed for $15 \mathrm{~s}$ and then allowed to stand for $30 \mathrm{~min}$ at $20^{\circ} \mathrm{C}$. Absorption was measured at $765 \mathrm{~nm}$ using a UV-Vis spectrophotometer, and the result was expressed as mg gallic acid $100 \mathrm{~g}^{-1}$ dry weight.

\subsection{Ellagic acid content}

To determine the total amount of ellagic acid, the fruit samples $(5 \mathrm{~g})$ were extracted and hydrolyzed in $50 \%(\mathrm{v} / \mathrm{v})$ aqueous methanol according to the procedure described by Hakkinen et al. [25]. The samples were heated to $85{ }^{\circ} \mathrm{C}$ for $20 \mathrm{~h}$ in $0.6 \mathrm{M} \mathrm{HCl}$ and $0.15 \%$ ascorbic acid. Samples were then centrifuged at $10,000 \mathrm{~g}$ for $5 \mathrm{~min}$. The supernatant of each sample was diluted with distilled water to twice the volume, placed on a SepPak C18 column and eluted with $1.4 \mathrm{~mL}$ of methanol before analysis on a HPLC apparatus (Shimadzu LC 10, Shimadzu, Kyoto, Japan) equipped with a UV/Vis detector (mod. SPD-M10A 230 V) and a Prodigy ODS3 $100 \AA$ Å column $(250 \times 4.6 \mathrm{~mm}$, particle size $5 \mu \mathrm{m})$ (Phenomenex, Torrance, CA, USA). The mobile phase was a linear binary gradient with solvent A (50 mM acetic acid and 5\% (v/v) acetonitrile) and solvent $\mathrm{B}$ [acetonitrile/5\% (v/v) $\mathrm{MeOH}$ ] at a flow rate of

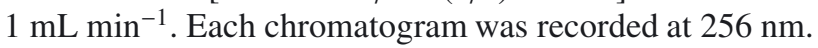

\subsection{Statistical analysis}

All data were statistically analyzed by ANOVA using the SPSS 20 software package (www.ibm.com/software/ analytics/spss). To separate treatment means within each measured parameter, Duncan's multiple range test was performed 
Table I. Effects of farming system and frozen storage on hunter color parameters $\mathrm{L}^{*}$ (brightness), $\mathrm{a}^{*}\left(+\mathrm{a}^{*}=\right.$ red; $-\mathrm{a}^{*}=$ green) and $\mathrm{b}^{*}\left(+\mathrm{b}^{*}=\right.$ yellow; -b = blue), hue $\left(\mathrm{h}^{\circ}\right)$, Chroma $\left(\mathrm{C}^{*}\right)$ of two strawberry cultivars 'Sabrina' and 'Ventana'.

\begin{tabular}{lcccccc}
\hline Farming system & Storage & $\mathrm{L}^{*}$ & $\mathrm{a}^{*}$ & $\mathrm{~b}^{*}$ & $\mathrm{~h}^{\circ}$ & $\mathrm{C}^{*}$ \\
\hline cv 'Sabrina' & & & & & & \\
Organic & Fresh & 19.3 & $42.2 \mathrm{a}$ & 33.1 & 38 & $53.7 \mathrm{a}$ \\
& Frozen & 18.8 & $44.3 \mathrm{a}$ & 32.4 & 36.1 & $54.9 \mathrm{a}$ \\
& Mean & 19.1 & 43.3 & 32.8 & 37.1 & 54.3 \\
Conventional & Fresh & 17.6 & $44.5 \mathrm{a}$ & 30.1 & 34.1 & $53.8 \mathrm{a}$ \\
& Frozen & 14.1 & $38.1 \mathrm{~b}$ & 24.2 & 32.4 & $45.2 \mathrm{~b}$ \\
& Mean & 15.9 & 41.3 & 27.2 & 33.3 & 49.5 \\
Significance & & & & & $*$ \\
Farming (F) & & $* *$ & $\mathrm{NS}$ & $* *$ & $* *$ & $* *$ \\
Storage (S) & & $\mathrm{NS}$ & $\mathrm{NS}$ & $\mathrm{NS}$ & $\mathrm{NS}$ & $\mathrm{NS}$ \\
F $\times$ S & & $\mathrm{NS}$ & $*$ & $\mathrm{NS}$ & $\mathrm{NS}$ & $* *$ \\
\hline cv 'Ventana' & & & & & \\
Organic & Fresh & 27.6 & 37.7 & 25.2 & 33.8 & 45.4 \\
& Frozen & 24.0 & 40.6 & 26.0 & 32.4 & 48.3 \\
& Mean & 25.8 & 39.1 & 25.6 & 33.1 & 46.8 \\
Conventional & Fresh & 15.0 & 28.1 & 16.3 & 30.2 & 32.5 \\
& Frozen & 14.0 & 33.9 & 16.1 & 25.4 & 37.5 \\
Significance & Mean & 14.5 & 31.0 & 16.2 & 27.8 & 35.0 \\
Farming (F) & & & & & & $*$ \\
Storage (S) & & $* *$ & $* *$ & $* *$ & $*$ & $\mathrm{NS}$ \\
\hline F $\times$ S & & $\mathrm{NS}$ & $\mathrm{NS}$ & $\mathrm{NS}$ & $\mathrm{NS}$ & $\mathrm{NS}$ \\
\hline
\end{tabular}

Means for the two farming systems over the two postharvest storage treatments are reported in italic font. Within columns, means with different letters are significantly different according to Duncan's test $(P \leqslant 0.05)$. NS, $* * *$ are non-significant or significant at $P \leqslant 0.05$ or 0.01 , respectively.

at $P<0.05$. Principal component analysis (PCA) using a correlation matrix was performed on quality attributes to assess relationships among variables and treatments, and also to determine which traits were the most effective in discriminating between the farming system and postharvest storage. PCA outputs include treatment component scores and variable loading to each selected component. The first two components PC1 and PC2 were selected for the ordination analysis, and the correlation between the original traits and the respective PC was calculated. Loadings $>|0.6|$ indicate significant correlations between the original variables and the extracted components [26].

\section{Results and discussion}

\subsection{Color}

Strawberry surface color has been generally regarded by consumers as indicative of the overall fruit quality, and the intensity of the red hue in particular has been associated arbitrarily with sweetness $[27,28]$. In both cultivars, the changes in Hunter color parameters were mainly due to the farming system and, to a lesser degree, to the effect of postharvest frozen storage. For the 'Sabrina' cultivar, no significant differences were observed between the fresh and thawed after frozen storage fruits, whereas for the 'Ventana' cultivar, the brightness ( $\mathrm{L}^{*}$ ) of fresh strawberry fruit (avg. 21.3) was $12.2 \%$ higher than the frozen ones (avg. 19.0), while an opposite trend was observed for the redness $\left(a^{*}\right)$ parameter, with the highest values recorded in frozen (average 37.2) compared with fresh berries (average 32.9) (table I).

When averaged over the storage treatment, organic farming significantly increased the $\mathrm{L}^{*}, \mathrm{a}^{*}, \mathrm{~b}^{*}, \mathrm{~h}^{\circ}$ and $\mathrm{C}^{*}$ in 'Sabrina' by $20.1 \%, 4.8 \%, 20.5 \%, 11.4 \%$ and $9.7 \%$, respectively, in comparison with those recorded in the conventional farming system (table I). The Hunter color parameters were more pronounced in 'Ventana' since the $\mathrm{L}^{*}, \mathrm{a}^{*}, \mathrm{~b}^{*}, \mathrm{~h}^{\circ}$ and $\mathrm{C}^{*}$ values of strawberry fruit from organic farming were significantly higher by $77.9 \%, 26.1 \%, 58.0 \%, 19.0 \%$ and $33.7 \%$, respectively, when compared with those observed in the conventional strawberry crop (table I).

Overall, in both cultivars the color of organic fruit was brighter and more vivid (higher $\mathrm{L}^{*}$ and $\mathrm{C}^{*}$ values). The results reported in the current experiment are in contrast with those recorded by Crecente-Campo et al. [27], who observed that the color of organic strawberry fruit (cv. 'Selva') was darker, less vivid and tended to be redder (lower L*, C*, $\mathrm{h}^{\circ}$, values) in comparison with the conventional farming system. Explanations for this disagreement could be attributed to genetic, environmental and agronomic differences between 
Table II. Effects of farming system and frozen storage on fruit mean weight (MW), dry matter (DM), firmness, juice pH, total soluble solid (TSS) content, titratable acidity (TA), and reducing sugars (RS) of two strawberry cultivars 'Sabrina' and 'Ventana'.

\begin{tabular}{|c|c|c|c|c|c|c|c|c|}
\hline Farming system & Storage & $\begin{array}{c}\text { MW } \\
\left.\text { (g fruit }^{-1}\right)\end{array}$ & $\begin{array}{l}\mathrm{DM} \\
(\%)\end{array}$ & $\begin{array}{l}\text { Firmness } \\
\left(\mathrm{kg} \mathrm{cm}^{-2}\right)\end{array}$ & $\mathrm{pH}$ & $\begin{array}{c}\text { TSS } \\
\left({ }^{\circ} \text { Brix }\right)\end{array}$ & $\begin{array}{l}\text { TA } \\
(\%)\end{array}$ & $\begin{array}{l}\mathrm{RS} \\
(\%) \\
\end{array}$ \\
\hline \multicolumn{9}{|l|}{ cv 'Sabrina' } \\
\hline \multirow[t]{3}{*}{ Organic } & Fresh & 11.0 & 9.1 & $1.3 \mathrm{a}$ & 3.5 & $7.3 \mathrm{ab}$ & 0.85 & 4.2 \\
\hline & Frozen & 10.4 & 8.7 & $0.3 \mathrm{c}$ & 3.5 & $6.4 \mathrm{~b}$ & 0.84 & 5.2 \\
\hline & Mean & 10.7 & 8.9 & 0.8 & 3.5 & 6.8 & 0.84 & 4.7 \\
\hline \multirow[t]{3}{*}{ Conventional } & Fresh & 16.2 & 8.8 & $1.1 \mathrm{a}$ & 3.7 & $7.7 \mathrm{a}$ & 0.72 & 4.9 \\
\hline & Frozen & 10.4 & 8.0 & $0.6 \mathrm{~b}$ & 3.7 & $5.3 \mathrm{c}$ & 0.76 & 4.0 \\
\hline & Mean & 13.3 & 8.4 & 0.8 & 3.7 & 6.5 & 0.74 & 4.5 \\
\hline \multicolumn{9}{|l|}{ Significance } \\
\hline Farming (F) & & $* *$ & NS & NS & $* *$ & $*$ & NS & NS \\
\hline Storage (S) & & $* *$ & NS & $* *$ & NS & $* *$ & NS & NS \\
\hline $\mathrm{F} \times \mathrm{S}$ & & NS & NS & $*$ & NS & $* *$ & NS & NS \\
\hline \multicolumn{9}{|l|}{ cv 'Ventana' } \\
\hline \multirow[t]{3}{*}{ Organic } & Fresh & 11.9 & 7.5 & $1.3 \mathrm{a}$ & 3.6 & $6.3 \mathrm{a}$ & 0.63 & 3.5 \\
\hline & Frozen & 9.1 & 8.7 & $0.2 \mathrm{~b}$ & 3.6 & $6.4 \mathrm{a}$ & 0.91 & 4.2 \\
\hline & Mean & 10.5 & 8.1 & 0.7 & 3.6 & 6.3 & 0.77 & 3.9 \\
\hline \multirow[t]{3}{*}{ Conventional } & Fresh & 17.8 & 6.2 & $1.3 \mathrm{a}$ & 3.7 & $6.5 \mathrm{a}$ & 0.50 & 4.4 \\
\hline & Frozen & 12.8 & 6.2 & $0.3 \mathrm{~b}$ & 3.7 & $5.0 \mathrm{~b}$ & 0.71 & 3.7 \\
\hline & Mean & 15.3 & 6.2 & 0.7 & 3.7 & 5.8 & 0.60 & 4.0 \\
\hline \multicolumn{9}{|l|}{ Significance } \\
\hline Farming (F) & & $* *$ & $* *$ & $* *$ & $*$ & $*$ & $*$ & NS \\
\hline Storage (S) & & $* *$ & NS & $* *$ & NS & $* *$ & $* *$ & NS \\
\hline $\mathrm{F} \times \mathrm{S}$ & & NS & NS & NS & NS & $* *$ & NS & NS \\
\hline
\end{tabular}

Means for the two farming systems over the two postharvest storage treatments are reported in italic font. Within columns, means with different letters are significantly different according to Duncan's test $(P \leqslant 0.05)$. NS, $* * *$ are non-significant or significant at $P \leqslant 0.05$ or 0.01 , respectively.

the two experiments. Moreover, the color of 'Ventana' fruit became darker and redder after frozen storage. This was in agreement with the findings of Koyuncu [29], who reported similar color changes in the three strawberry cultivars 'Camarosa', 'Cavendish' and 'Chandler', subjected to storage at $0{ }^{\circ} \mathrm{C}$.

\subsection{Mean weight, firmness and flavor compounds}

The fruit mean weight in both strawberry cultivars was significantly affected by the storage and farming system. For instance, the fruit mean weight was negatively affected by frozen storage since weight decreased in frozen fruits ( $t a-$ ble II). Moreover, organic strawberries had a lower mean weight, as previously reported by Abu-Zahra and Tahboub [30] for the cultivar 'Camarosa', although this may not always be true according to Baruzzi et al. [31] and Conti et al. [32], who analyzed different Italian strawberry cultivars. It is well established that organic materials (fish meal or powder, feather, alfalfa, soybean, bone, blood and meat meal) are less concentrated nutrient sources than conventional fertilizers and are characterized by low mineralization rates [33]. Therefore, the lowest fruit yield and fruit mean weight under organic farming could be attributed to a reduced availability of nutrients, in particular $\mathrm{N}$, at the right moment for the crop nutrient demand [32].

'Ventana' berries from organic farming were significantly smaller (by $31.3 \%$ ) than those from conventional farming, but had significantly greater dry matter percentage $(30.6 \%)$ ( $t a-$ ble II), which is in line with the findings of [34]. The greater dry matter percentage may be due to a higher proportion of cell wall content in the small-sized 'Ventana' organic berries compared with the large-sized organic fruits $[35,36]$ as a result of the lower nitrogen concentration in organic fruit [37].

The fruit firmness, an important quality trait in determining consumer acceptability [38], was affected by the farming system and the postharvest frozen storage (table II). Significant interaction between the farming system and the frozen storage was observed in 'Sabrina'. The highest firmness values were recorded in fresh fruits under both organic and conventional management, whereas the lowest values were observed in frozen organic fruits. Strawberry is a soft fruit that suffers a rapid loss of firmness during ripening, which contributes greatly to its short shelf life [39]. In a recent study, Klat et al. [40] showed that postharvest life of fruits depends on their firmness, which is also related to fertilized achenes and thus dependent on successful pollination. Higher levels of plant hormones such as auxin and gibberelic acid 
enhance firmness and thus shelf life by limiting the expression of fruit-softening proteins in particular expansions [41]. The firmness of the fruits in both cultivars reduced sharply during storage, mainly due to loss of cell wall material, which is more pronounced in the cortical tissue than in the pith tissue [42]. Furthermore, the fruit softening of strawberry fruit is due to their particular structure, characterized by large cells and thin cell walls [42]. Our results concerning frozen storage are in line with those of Ali et al. [43], who demonstrated that strawberry (cv. 'Sweet Charlie') firmness decreased significantly during postharvest storage at $0{ }^{\circ} \mathrm{C}$ for 15 days.

The juice $\mathrm{pH}$ in both cultivars was significantly affected by the farming system, with the highest values recorded in conventional farming (on average 3.7 vs. 3.5 in organic farming). The values of the juice $\mathrm{pH}$ recorded in the current experiment were consistent with the findings of Koyuncu [29] in several strawberry cultivars (with $\mathrm{pH}$ values ranging between 3.4 and 4.2). Contrarily to juice $\mathrm{pH}$, the highest titratable acidity (TA) in the cultivar 'Ventana' was recorded in the organic farming system, whereas no significant difference among treatments was observed in TA in 'Sabrina'. This negative correlation between $\mathrm{pH}$ and titratable acidity could be expected, considering that fruit juice $\mathrm{pH}$ is determined primarily by organic acids [44]. Moreover, the titratable acidity recorded in 'Ventana' fruits subjected to frozen storage was significantly higher than that recorded at harvest, whereas no significant difference among treatments was observed in 'Sabrina' (table II). The increase in titratable acidity (e.g. citric acid) during frozen storage could be attributed to the changes in the permeability of the cell membrane, resulting in water leaving the cells and thus enhancing the solute concentrations [45].

The total soluble solid (TSS) content of the juice, which comprises soluble carbohydrates (mainly glucose and fructose), has been regarded by convention as a measure of sweetness in most fruits including strawberry. In the current experiment, the TSS content in both cultivars was significantly affected by the farming system, frozen storage and their interaction, with the lowest values recorded in frozen fruits from the conventional system (table II). Both cultivars were found to be significantly different in their TSS contents, with the highest values recorded in 'Sabrina' (average $6.6^{\circ}$ Brix vs. $6.0^{\circ}$ Brix in 'Ventana'). When averaged over the farming system, the TSS content decreased sharply in both cultivars after frozen storage for 6 months. Except for 'Ventana' from organic farming, the TSS content decreased in both cultivars after frozen storage for 6 months. Because of the highly freezable water content in berries, freezing implies significant cellular damage, leading to significant losses in product quality (i.e. soluble solids) [46]. Finally, irrespective of storage, the organic management resulted in higher values of soluble solids in both cultivars (table II). These results are in agreement with several published studies $[12,30,32,47]$ which found that organic fruits have a higher TSS content than conventionally grown fruits. The higher TSS recorded in 'Ventana' grown organically could be due to lower fruit water content (i.e. greater dry matter percentage), as observed in previous studies [34,36]. Furthermore, the higher availability of $\mathrm{N}$ in the conventional farming may also explain the lower TSS in berries, as in
Cantliffe et al. [43], and shows that increasing amounts of $\mathrm{N}$ will decrease strawberry fruit TSS.

\subsection{Antioxidant activity and bioactive compounds}

In the last two decades, antioxidant activity and bioactive compounds found in vegetables have generated significant interest among consumers and researchers due to their healthbenefit properties [49]. In the current experiment, the effects of the farming system and postharvest frozen storage on the hydrophilic (HAA) and lipophilic (LAA) antioxidant activities were more pronounced in 'Ventana' than in 'Sabrina'. The HAA values of the frozen 'Sabrina' fruits $(18.9 \mathrm{mmol}$ ascorbic acid eq $100 \mathrm{~g}^{-1} \mathrm{FW}$ ) were significantly higher (29.4\%) than those recorded in fruits analyzed fresh after harvest (14.6 mmol ascorbic acid eq $100 \mathrm{~g}^{-1} \mathrm{FW}$ ) (table III), whereas the lowest HAA values in 'Ventana' were observed in conventional farming without storage (table III). Moreover, no significant differences among treatments were recorded for LAA in 'Sabrina' (18.4 mmol Trolox eq $100 \mathrm{~g}^{-1} \mathrm{FW}$ ), whereas LAA in 'Ventana' was significantly higher in conventional in comparison with organic, and in fresh than in frozen fruits (table III).

Total ascorbic acid has long been considered an important nutritional compound of strawberries [50], since it offers potential benefits to human health for protection against diseases [51]. No significant differences among treatments were recorded in total ascorbic acid (AA) in 'Ventana', while 'Sabrina' was significantly affected by postharvest frozen storage, with the highest values recorded in fresh fruits compared with the fruits thawed after frozen storage ( $t a-$ ble III). Similar results were found by Perez et al. [52] and Koyuncu [29] in two studies related to the storage of different strawberry cultivars at 2 and $0{ }^{\circ} \mathrm{C}$, respectively. Similarly, Lisiewska and Kmiecik [53] observed that freezing resulted in a small decrease in the vitamin $\mathrm{C}$ content, which was reduced by $15-18 \%$ in broccoli and by $6-13 \%$ in cauliflower after 12 months of frozen storage at $-30{ }^{\circ} \mathrm{C}$. Our results also demonstrated that the cultivation system did not significantly affect the total ascorbic acid content in both cultivars. The literature on this topic is inconclusive. For instance, Asami et al. [54] studied the 'Northwest Totem' strawberry variety and demonstrated that the AA contents in organically grown samples were significantly higher (32.6 mg $100 \mathrm{~g}^{-1} \mathrm{FW}$ ) than the contents for conventionally grown fruits $\left(27.1 \mathrm{mg} 100 \mathrm{~g}^{-1} \mathrm{FW}\right)$. Similarly, Jin et al. [13] indicated that the AA content was higher in organically cultivated (avg. $1.9-2.7 \mathrm{mmol} \mathrm{kg}^{-1} \mathrm{FW}$ ) versus conventionally cultivated $\left(1.3-2.3 \mathrm{mmol} \mathrm{kg}{ }^{-1} \mathrm{FW}\right)$ 'Earliglow' and 'Allstar' strawberries. However, Hakala et al. [55] indicated that organic cultivation had no effect on the vitamin C content of the 'Honeoye' (62.5 mg $100 \mathrm{~g}^{-1} \mathrm{FW}$ ), 'Jonsok' (45.0 mg $\left.100 \mathrm{~g}^{-1} \mathrm{FW}\right)$ and 'Polka' (52.5 mg $\left.100 \mathrm{~g}^{-1} \mathrm{FW}\right)$ varieties, whereas Cardoso et al. [56] showed that the AA content was significantly lower in organic strawberries $(30.7 \mathrm{mg}$ $100 \mathrm{~g}^{-1} \mathrm{FW}$ ) than in conventional strawberries $(42.4 \mathrm{mg}$ $100 \mathrm{~g}^{-1} \mathrm{FW}$ ).

No significant differences among treatments were recorded for total phenol content in 'Sabrina' (106.4 mg gallic acid $100 \mathrm{~g}^{-1}$ DW), whereas a significant effect of the farming 
Table III. Effect of farming system and frozen storage on hydrophilic (HAA) and lipophilic (LAA) antioxidant activities, total ascorbic acid (AA), total phenols (TP) and ellagic acid contents of two strawberry cultivars 'Sabrina' and 'Ventana'.

\begin{tabular}{|c|c|c|c|c|c|c|}
\hline $\begin{array}{l}\text { Farming } \\
\text { system }\end{array}$ & Storage & $\begin{array}{c}\text { HAA } \\
\text { mmol ascorbic acid eq } \\
100 \mathrm{~g}^{-1} \mathrm{FW}\end{array}$ & $\begin{array}{c}\text { LAA } \\
\text { Mmol Troloxeq. } \\
100 \mathrm{~g}^{-1} \mathrm{FW}\end{array}$ & $\begin{array}{c}\text { AA } \\
\mathrm{mg} 100 \mathrm{~g}^{-1} \mathrm{FW}\end{array}$ & $\begin{array}{c}\mathrm{TP} \\
\text { mg gallic acid } \\
100 \mathrm{~g}^{-1} \mathrm{DW}\end{array}$ & 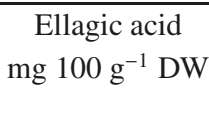 \\
\hline \multicolumn{7}{|l|}{ cv 'Sabrina' } \\
\hline \multirow[t]{3}{*}{ Organic } & Fresh & 15.7 & 19.7 & 72.8 & 106.8 & 55.0 \\
\hline & Frozen & 19.6 & 17.7 & 41.8 & 104.2 & 49.8 \\
\hline & Mean & 17.7 & 18.7 & 57.3 & 105.5 & 52.4 \\
\hline \multirow[t]{3}{*}{ Conventional } & Fresh & 13.6 & 18.1 & 58.0 & 100.5 & 60.4 \\
\hline & Frozen & 18.2 & 18.1 & 49.3 & 114.2 & 51.9 \\
\hline & Mean & 15.9 & 18.1 & 53.7 & 107.3 & 56.2 \\
\hline \multicolumn{7}{|l|}{ Significance } \\
\hline Farming $(\mathrm{F})$ & & NS & NS & NS & NS & $*$ \\
\hline Storage (S) & & $* *$ & NS & $* *$ & NS & $* *$ \\
\hline $\mathrm{F} \times \mathrm{S}$ & & NS & NS & NS & NS & NS \\
\hline \multicolumn{7}{|l|}{ cv 'Ventana' } \\
\hline \multirow[t]{3}{*}{ Organic } & Fresh & $24.9 \mathrm{a}$ & 15.2 & 23.7 & 96.7 & 55.6 \\
\hline & Frozen & $19.7 \mathrm{~b}$ & 12.6 & 21.8 & 88.4 & 44.9 \\
\hline & Mean & 22.3 & 13.9 & 21.8 & 92.6 & 50.3 \\
\hline \multirow[t]{3}{*}{ Conventional } & Fresh & $12.0 \mathrm{c}$ & 21.7 & 38.9 & 111.6 & 57.0 \\
\hline & Frozen & $24.7 \mathrm{a}$ & 17.6 & 40.5 & 98.5 & 46.7 \\
\hline & Mean & 18.4 & 19.7 & 39.7 & 105.0 & 51.9 \\
\hline \multicolumn{7}{|l|}{ Significance } \\
\hline Farming $(\mathrm{F})$ & & $* *$ & $* *$ & NS & $*$ & NS \\
\hline Storage (S) & & $* *$ & $*$ & NS & NS & $* *$ \\
\hline $\mathrm{F} \times \mathrm{S}$ & & $* *$ & NS & NS & NS & NS \\
\hline
\end{tabular}

Means for the two farming systems over the two postharvest storage treatments are reported in italic font. Within columns, means with different letters are significantly different according to Duncan's test $(P \leqslant 0.05)$. NS, $* *^{*}$ are non-significant or significant at $P \leqslant 0.05$ or 0.01 , respectively.

system was observed in 'Ventana', since an increase of $13.4 \%$ in total phenolic content was observed on fruits harvested from the conventional system (table III). Similarly to the total phenols, the ellagic acid, a naturally occurring polyphenolic secondary metabolite that accumulates in strawberry fruit [57], was affected by the cultivation management system but only in 'Sabrina'. The ellagic acid content in 'Sabrina' recorded in the conventional farming was significantly higher by $7.2 \%$ than in organic strawberries (table III). Finally, our results showed that the ellagic acid content significantly decreased by $11.9 \%$ and $18.6 \%$ in 'Sabrina' and 'Ventana', respectively, when fruits were stored at $-40{ }^{\circ} \mathrm{C}$ for 6 months. This is in agreement with the findings of Hakkinen and Torronen [9], who reported a $40 \%$ decrease in ellagic acid contents in strawberry during 9 months of storage in a freezer, and also in line with the results of de Ancos et al. [58], who showed a degradation of ellagic acid (19-21\%) in raspberry after 365 days at $-20{ }^{\circ} \mathrm{C}$. It is generally proved that ellagic acid is a phenolic compound strongly linked to the cell wall [59]. The losses of ellagic acid in both berries during storage at $-40{ }^{\circ} \mathrm{C}$ for 6 months could be related to a severe cellular disruption which could be produced by release of oxidoreductase ionic forms of the enzyme polyphenoloxidase (PPO) linked to the cell wall [58].

\subsection{Principal component analysis}

As defined by Lawless and Heymann [60], "PCA is a multivariate technique used to summarize and extract trends when many variables are used". PCA formulates new variables called principal components (PC), which summarize the variability of the original variables better and are correlated with them. The first three PCs were associated with Eigen values $>1$, and explained $84.5 \%$ of the total variance, with PC1 accounting for $44.3 \%$ and PC2 for $30.0 \%$ (table IV). PC1 was positively and significantly correlated with $C^{*}, h^{\circ}, a^{*}, b^{*}$, fruit dry matter, total soluble solids content and titratable acidity (table IV). PC2 was positively correlated with lipophilic antioxidant activity, total ascorbic acid, total phenols and ellagic acid content, and negatively correlated with hydrophilic antioxidant activity. Moreover PC3, which explained $10.1 \%$ of the variance, was negatively correlated with $\mathrm{L}^{*}$ (table IV).

Generally, the first two PCs account for meaningful variance; therefore only $\mathrm{PC} 1$ and $\mathrm{PC} 2$ were retained and interpreted (figures $1 A, B$ ). The loading plot (figure 1A) illustrates the relationships among variables (i.e. quality attributes), where two vectors with an angle $>90^{\circ}$ are positively correlated and two vectors with an angle $>90^{\circ}$ are negatively 
Table IV. Correlation coefficient for each quality attribute with respect to the first three principal components PC1, PC2, and PC3 eigenvalues, relative and cumulative proportion of total variance.

\begin{tabular}{lccc}
\hline \multirow{2}{*}{ Trait } & \multicolumn{3}{c}{ Principal components $(\mathrm{PC})^{1}$} \\
\cline { 2 - 4 } & PC1 & PC2 & PC3 \\
\hline $\mathrm{L}^{*}$ & 0.473 & -0.556 & $\mathbf{- 0 . 6 1 5}$ \\
$\mathrm{C}^{*}$ & $\mathbf{0 . 9 8 1}$ & 0.034 & 0.188 \\
$\mathrm{~h}^{\circ}$ & $\mathbf{0 . 8 2 1}$ & 0.310 & -0.165 \\
$\mathrm{a}^{*}$ & $\mathbf{0 . 9 6 8}$ & -0.109 & 0.203 \\
$\mathrm{~b}^{*}$ & $\mathbf{0 . 9 6 8}$ & 0.143 & 0.071 \\
Fruit dry matter & $\mathbf{0 . 9 6 3}$ & -0.049 & -0.005 \\
Total soluble solids & $\mathbf{0 . 6 5 2}$ & 0.471 & -0.429 \\
Reducing sugars & 0.587 & 0.279 & 0.064 \\
Titratable acidity & $\mathbf{0 . 6 6 1}$ & -0.489 & 0.461 \\
Hydrophilic antioxidant activity & -0.039 & $\mathbf{- 0 . 8 5 2}$ & 0.224 \\
Lipophylic antioxidant activity & -0.362 & $\mathbf{0 . 8 8 2}$ & 0.145 \\
Ascorbic acid & 0.324 & $\mathbf{0 . 7 6 4}$ & 0.406 \\
Total phenols & -0.290 & $\mathbf{0 . 7 8 1}$ & 0.280 \\
Ellagic acid & 0.148 & $\mathbf{0 . 7 2 5}$ & -0.471 \\
Eigenvalue & 6.21 & 4.20 & 1.42 \\
Percentage of variance & 44.3 & 30.0 & 10.1 \\
Cumulative variance & 44.3 & 74.3 & 84.5 \\
\hline
\end{tabular}

${ }^{1}$ The bold values indicate the most relevant characters for each principal component.

correlated [44]. For instance, ellagic acid content was positively correlated with total ascorbic acid and, to a lesser degree, total soluble solids and $\mathrm{h}^{\circ}$, whereas total soluble solids content was highly correlated with reducing sugars. Similarly, total phenol content was more strongly correlated with lipophilic antioxidant activity than ellagic acid content. A negative correlation between total phenols and titratable acidity was also observed (figure 1A).

The score plot of components 1 and 2 (figure $1 B$ ) separates treatments into four groups. The positive side of PC1 (quadrants 2 and 4) included fruits of 'Sabrina' and 'Ventana' at harvest and thawed after frozen storage from organic farming management, but also fresh conventional 'Sabrina' fruits. The treatments of the upper right quadrant, in particular organic and conventional 'Sabrina' fruits at harvest, were characterized by high total soluble solids, ascorbic acid content and $\mathrm{h}^{\circ}$, whereas the cluster in the lower right quadrant represents fruits characterized by higher brightness $\left(\mathrm{L}^{*}\right)$ (figure $1 B$ ). The negative side of PC1 (quadrants 1 and 3) corresponded to conventional fruits of 'Ventana' at harvest and thawed after frozen storage, but also to conventional 'Sabrina' stored at $-40{ }^{\circ} \mathrm{C}$ for 6 months. The treatments of the upper left quadrant (1) were characterized by high lipophilic antioxidant activity and total phenol content, whereas those of the lower left quadrant (3) had relatively the lowest fruit quality among the treatments (figure $1 B$ ). The PCA carried out in the current experiment demonstrated the ability of this analysis to track the effects of farming management and postharvest storage fruit quality of two strawberry cultivars and could constitute the basis of future strategies to optimize quality [61].
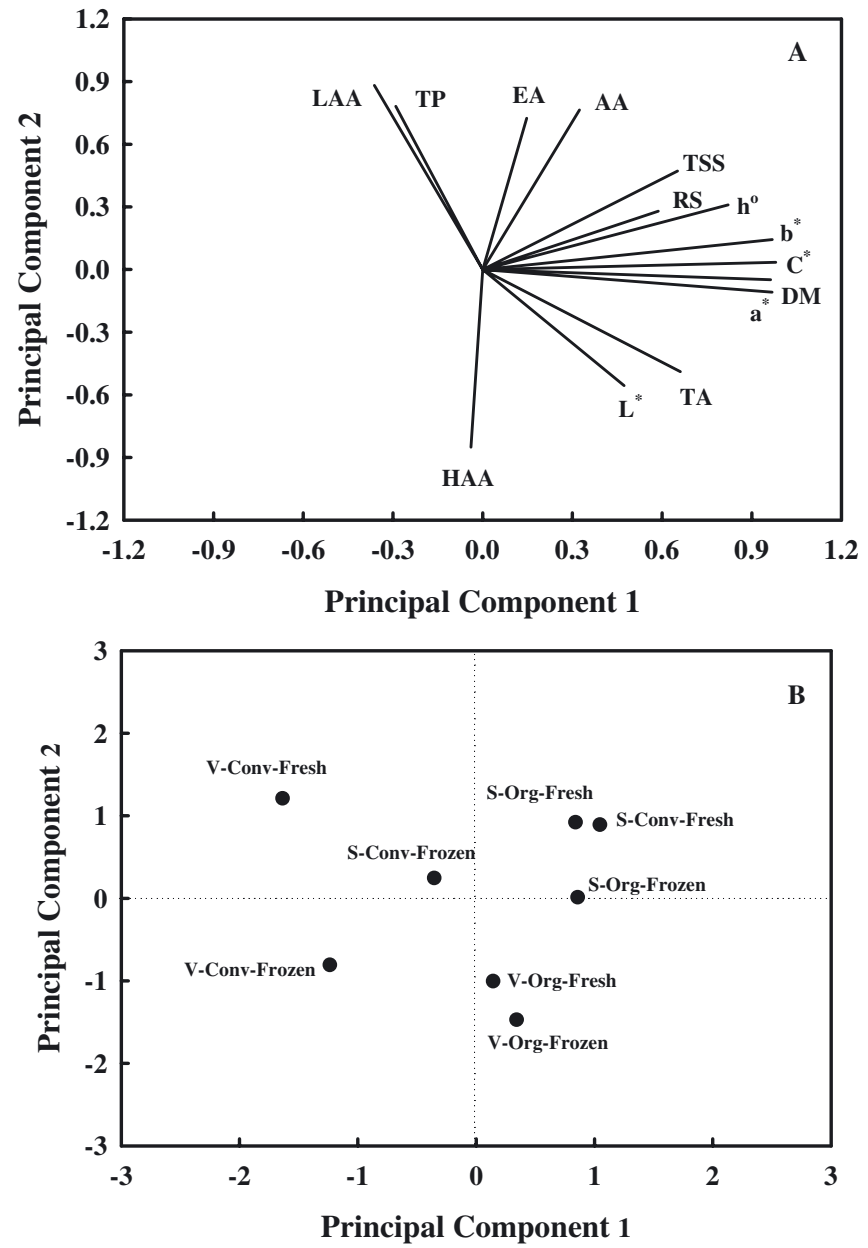

Figure 1. (A) Principal component loading plot and (B) scores of principal component analysis of physicochemical fruit traits of two strawberry cultivars (S, 'Sabrina'; V, 'Ventana') as a function of farming system management (Org, organic; Conv, conventional), and postharvest storage (Fresh, at harvest; Thawed after frozen storage at $-40{ }^{\circ} \mathrm{C}$ for 6 months). $\mathrm{L}^{*}$, lightness; $\mathrm{C}^{*}$, chroma; $\mathrm{h}^{\circ}$, hue angle; $\mathrm{a}^{*}$, redness; $\mathrm{b}^{*}$, yellowness; DM, fruit dry matter; TSS, total soluble solid content; RS, reducing sugars; TA, titratable acidity; HAA, hydrophilic antioxidant activity; LAA, lipophilic antioxidant activity; AA, ascorbic acid; TP, total phenols; EA, ellagic acid.

\section{Conclusion}

As a summary, the results of the two trials showed that the skin lightness, fruit firmness, total soluble solids and ellagic acid contents scored higher at harvest than thawed after storage at $-40{ }^{\circ} \mathrm{C}$ for 6 months. Postharvest frozen storage positively affected the hydrophilic antioxidant activity, leaving reducing sugars and total phenol contents without significant alterations. Our results also demonstrated that for both cultivars, the color of organic fruits was brighter and more vivid (higher $\mathrm{L}^{*}$ and $\mathrm{C}^{*}$ values). Strawberries had higher HAA in organic 'Ventana' and higher ellagic acid content in conventional 'Sabrina', indicating that cultivar characteristics should be taken into consideration in choosing a cultivar for a specific farming system. This could be critical to fully exploit the potential of organic horticulture. 


\section{References}

[1] FAO/WHO, Codex Alimentarius: Organically produced foods, 3 ed., 1999, 63 p.

[2] Bourn D., Prescott J.A., Comparison of the nutritional value, sensory qualities, and food safety of organically and conventionally produced foods, Crit. Rev. Food Sci. Nutr. 42 (2002) $1-34$.

[3] Magkos F., Arvaniti F., Zampelas A., Organic food: Buying more safety or just peace of mind? A critical review of the literature, Crit. Rev. Food Sci. Nutr. 46 (2006) 23-56.

[4] CSO(2013) (Centro Servizi Ortofrutticoli) Database. CSO http://www.csoservizi.com.

[5] Giampieri F., Tulipani S., Alvarez-Suarez J.M., Quiles J.L., Mezzetti B., Battino M., The strawberry: Composition, nutritional quality, and impact on human health, Nutrition 28 (2012) 9-19.

[6] Sun J., Chu Y.F., Wu X., Liu R.H., Antioxidant and antiproliferative activities of common fruits, J. Agric. Food Chem. 50 (2002) 7449-7454.

[7] Maas J.L., Galletta G.J., Stoner G.D., Ellagic acid, an anticarcinogen in fruits, especially in strawberries: A review, Hort. Sci. 26 (1991) 10-14.

[8] Conney A.H., Enzyme induction and dietary chemicals as approaches to cancer chemoprevention: The Seventh DeWitt S. Goodman Lecture. Cancer Res. 63 (2003) 7005-7031.

[9] Häkkinen S. H.; Törrönen A.R., Content of flavonols and selected phenolic acids in strawberries and Vaccinium species: Influence of cultivar, cultivation site and technique, Food Res. 33 (2000) 517-524.

[10] Olsson M.E., Gustavsson K.G., Nilsson J., Ekvall J., Pillaua D., Sjöholm I., Svensson U., Åkesson B., Nyman M., Antioxidants, low molecular weight carbohydrates and total antioxidative capacity in strawberries (Fragaria $\times$ ananassa): Effects of cultivar, ripening, and storage, J. Agric. Food Chem. 52 (2004) 2490-2498.

[11] Olsson M.E., Andersson C.S., Oredsson S., Berglund R.H., Gustavsson K., Antioxidant levels and inhibition of cancer cell proliferation in vitro by extracts from organically and conventionally cultivated strawberries, J. Agric. Food Chem. 54 (2006) $1248-1255$

[12] Hargreaves J.C., Adl M., Warman P.R., Rupasinghe H.P.V., The effects of organic and conventional nutrient amendments on strawberry cultivation: Fruit yield and quality, J. Sci. Food Agric. 88 (2008) 2669-2675.

[13] Jin P., Wang S.Y., Wang C.Y., Zheng Y.H., Effect of cultural system and storage temperature on antioxidant capacity and phenolic compounds in strawberries, Food Chem. 124 (2011) $262-270$.

[14] Oszmiañski J., Wojdy1o A., KolniakJ., Effect of L-ascorbic acid, sugar, pectin and freeze-thaw treatment on polyphenol content of frozen strawberries, LWT - Food Sci. Technol. 42 (2009) 581-586.

[15] Wicklund, T., Rosenfeld, H. J., Martinsen, B. K., Sundfor, M. W., Lea, P., Bruun, T., Antioxidant capacity and colour of strawberry jam as influenced by cultivar and storage conditions, LWT- Food Sci.Technol.38 (2005) 387-391.

[16] Lindley M.G., The impact of food processing on antioxidants in vegetable oils, fruits and vegetables, Trends Food Sci. Technol. 9 (1998) 336-341.
[17] Garrote R.L., Bertone R.A., Osmotic concentration at low temperature of frozen strawberry halves. Effect of glycerol, glucose and sucrose solutions on exudate loss during thawing, Lebensm. Wiss. Technol. 22 (1989) 264-267.

[18] Council Regulation (EC) No 834/2007 of 28 June 2007 on organic production and labelling of organic products and repealing Regulation (EEC) No 2092/91, Official Journal of the European Union L 198, 1-23.

[19] McGuire, R.G., Reporting of objective color measurements, HortScience 27 (1992) 1254-1255.

[20] Fogliano V., Verde V., Randazzo G., Ritieni A., Method for measuring antioxidant activity and its application to monitoring the antioxidant capacity of wines, J. Agric Food Chem. 47 (1999) 1035-1040.

[21] Pellegrini N., Re R., Yang M. and Rice-Evans C., Screening of dietary carotenoids and carotenoid-rich fruit extracts for antioxidant activities applying 2,2-azinobis (3 ethylenebenzothiazoline-6- sulfonic acid radical cation decoloration assay, Methods. Enzymol. 299 (1999) 379-384.

[22] Re R., Pellegrini N., Proteggente A., Pannala A., Yang M.,RiceEvans C., Antioxidant activity applying an improved ABTS radical cation decolorization assay, J. Free Radic. Biol. Med. 26 (1999) 1231-1237.

[23] Kampfenkel K., Montagu M.V., Inzè D., Extraction and determination of ascorbate and dehydroascorbate from plant tissue, Ann. Biochem. 225 (1995) 165-167.

[24] Singleton V.L., Orthofer R., Lamuela-Raventos R.M., Analysis of total phenols and other oxidation substrates and antioxidants by means of Folin-Ciocalteu reagent, Meth. Enzymol. 299 (1999) 152-178.

[25] Häkkinen S.H., K?renlampi S.O., Heinonen I.M., Mykk?nen H.M., Törrönen A.R., HPLC method for screening of flavonoids and phenolic acids in berries, J. Sci. Food Agric. 77 (1998) 543-551.

[26] Matus I.M., Gonzales G., del Poso A., Evaluation of phenotypic variation in a Chilean collection of garlic (Allium sativum L.) clones using multivariate analysis, Plant Gen. Res. Newsl. 117 (1996) 31-36.

[27] Crecente-Campo J., Nunes-Damaceno M., Romero-Rodrìguez M.A., Vazquez-Oderiz M.L., Color, anthocyanin pigment, ascorbic acid and total phenolic compound determination in organic versus conventional strawberries (Fragaria $\times$ ananassa Duch, cv Selva), J. Food Comp. Anal. 28 (2012) 23-30.

[28] Hidaka S., Shimoda K., Investigation of the effects of color on judgments of sweetness using a taste adaptation method, Multisens. Res. 27 (2014) 189-205.

[29] Koyuncu M.A., Quality Changes of three Strawberry Cultivars during the Cold Storage, Eur. J. Hortic. Sci. 69 (2004) 193-200.

[30] Abu-Zahra T.R., Tahboub A.A. Strawberry (Fragaria $\times$ ananassa Duch) fruit quality grown under different organic matter sources in a plastic house at Hum-rat Al-Sahen, Acta Hortic. 807 (2009) 353-358.

[31] Baruzzi G., Faedi W., Lucchi P., Migani M., Sbrighi P., Turci P., Performance of Italian strawberry genotypes on fumigated, nonfumigated soils and organic culture, Acta Hortic. 842 (2009) 553-556.

[32] Conti S., Villari G., Faugno S., Melchionna G., Somma S., Caruso G., Effects of organic vs. conventional farming system on yield and quality of strawberry grown as an annual or biennial crop in southern Italy, Sci. Hortic. 180 (2014) 63-71.

[33] Gaskell M., Fouche B., Koike S., Lanini T., Mitchell J., Smith R., Organic vegetable production in California-Science and practice, HortTechnology 10 (2000) 699-713. 
[34] Reganold J.P., Andrews P.K., Reeve J.R., Carpenter-Boggs L., Schadt C.W., Alldredge J.R., Ross C.F., Davies N.M., Zhou J., Fruit and soil quality of organic and conventional strawberry ecosystems, PloS One 5 (2010) e12346.

[35] Amarante C.V.T., Steffens C.A., Luiz Mafra A., Albuquerque J.A., Yield and fruit quality of apple from conventional and organic production system, Pesqui. Agropecu. Bras. 43 (2008) 333-340.

[36] Pokhrel B., Laursen K.H., Petersen K.K., Yield, Quality, and nutrient concentrations of strawberry (Fragaria $\times$ ananassa Duch. cv.'Sonata') grown with different organic fertilizer strategies. J. Agric. Food Chem. 63 (2015) 5578-5586.

[37] Miner G.S., Poling E.B., Carroll D.E., Nelson L.A., Campbell C.R., Influence of fall nitrogen and spring nitrogen potassium applications on yield and fruit quality of 'Chandler' strawberry, J. Am. Soc. Hortic. Sci. 122 (1997) 290-295.

[38] Rouphael Y., Schwarz D., Krumbein A., Colla G., Impact of grafting on product quality of fruit vegetables, Sci. Hortic. 127 (2010) 172-179.

[39] Goulas V., Manganaris G.A., The effect of postharvest ripening on strawberry bioactive composition and antioxidant potential, J. Sci. Food Agric. 91 (2011) 1907-1914.

[40] Klatt B.K., Holzschuh A., Westphal C., Clough Y., Smit I., Pawelzik E., Tscharntke T., Bee pollination improves crop quality shelf life and commercial value, Proc. R. Soc. B: Biol. Sci. (2014) 281

[41] Given N.K., Venis M.A., Grierson D., Hormonal regulation of ripening in the strawberry, a non climacteric fruit, Planta 174 (1988) 402-406.

[42] Koh T.H., Melton L.D., Ripening-related changes in cell wall polysaccharides of strawberry cortical and pith tissues, Postharvest Biol. Technol. 26 (2004) 23-33.

[43] Ali A., Abrar M., Sultan M.T., Din A., Niaz B., Post-harvest physiochemical changes in full ripe strawberries during cold storage, J. Anim. Plant Sci. 21 (2011) 38-41.

[44] Sartono B., Affendi F.M., Syahfitri U.D., Sumertajaya I.M., Anggraeni Y., Analysis Variable, Ganda Bogor, Indonesia: Statistics Dept. Bogor Agricultural University (2003).

[45] Bartolomé A.P., Rupérez P., Fúster C., Non-volatile organic acids, $\mathrm{pH}$ and titratable acidity changes in pineapple fruit slices during frozen storage, J. Sci. Food Agric. 70 (1996) 475-480.

[46] Martínez-Navarrette N., Moraga G., Martínez-Monzó J., Botella F., Tirado N. Chiralt A., Mechanical and color changes associated to dehydrofreezing of strawberry, in Welti-Chanes J., Barbosa-Canvas G.V. and Aguilera J.M. (Eds.), Proceedings of the Eighth International Congress on Engineering and Food: ICEF-8, (2001), pp. 793-797, Technomic Publishing Company, Inc., Lancaster,PA.

[47] Abu-Zahra T.R., Al-Ismail K., Shatat F., Effect of organic and conventional systems on fruit quality of strawberry
(Fragaria $\times$ ananassa Duch) grown under plastic house conditions in the Jordan valley, Acta Hortic. 741 (2006) 159-171.

[48] Cantliffe D.J., Castellanos J.Z., Paranjpe A.V., Yield and quality of greenhouse-grown strawberries as affected by nitrogen level in coco coir and pine mark media, Proc. Fla. St. Hortic. Soc. 120 (2007) 157-161.

[49] Khanam U.K.S., Oba S., Yanase E., Murakami Y., Phenolic acids, flavonoids and total antioxidant capacity of selected leafy vegetables, J. Func. Food 4 (2012) 979-987.

[50] Scalzo J., Politi A., Pellegrini N., Mezzetti B., Battino M., Plant genotype affects total antioxidant capacity and phenolic contents in fruit, Nutrition 21 (2005) 207-13.

[51] Halliwell B., Aeschbach R., Loliger J, Aruoma O.I., The characterization of antioxidants, Food Chem. Toxicol. 33 (1995) 601-617.

[52] Perez A.G., Olias R., Olias J.M., Sanz C., Strawberry quality as a function of the "high pressure fast cooling" design, Food Chem. 62 (1998) 161-168.

[53] Lisiewska Z., Kmiecik W., Effect of level of nitrogen fertilizer, processing conditions and period of storage for frozen broccoli and cauliflower on vitamin C retention, Food Chem. 57 (1996) 267-270.

[54] Asami D.K., Hong Y., Barrett D.M., Mitchell A.E., Comparison of the total phenolic and ascorbic acid content of freeze-dried and air-dried marion berry, strawberry, and corn grown using conventional, organic, and sustainable agricultural practices, J. Agric. Food Chem. 51(2003) 1237-1241.

[55] Hakala M., Lapveteläinen A., Huopalahti R., Kallio H., Tahvonen R., Effects of varieties and cultivation conditions on the composition of strawberries, J. Food Comp. Anal. 16 (2003) 67-80.

[56] Cardoso P.C., Tomazini A.P.B., Stringheta P.C., Ribeiro S.M.R., Pinheiro-Sant'Ana H.M., Vitamin C and carotenoids in organic and conventional fruits grown in Brazil, Food Chem. 126 (2011) 411-416.

[57] Vattem D.A., Shetty K., Biological functionality of ellagic acid: A review, J. Agric. Food Chem. 29 (2005) 234-266.

[58] de Ancos B., González E.M., Cano M.P., Ellagic acid, vitamin $\mathrm{C}$, and total phenolic contents and radical scavenging capacity affected by freezing and frozen storage in raspberry fruit, J. Agric. Food Chem. 48 (2000) 4565-4570.

[59] Rommel A., Wrolstad R.E., Ellagic acid content of red raspberry juice as influenced by cultivars, processing, and enviromental factors, J. Agric. Food Chem. 41 (1993) 1951-1960.

[60] Lawless H., Heymann H., Sensory evaluation of food: Principles and practices, New York, NY: Springer (2010).

[61] Finnegan E., O’Beirne D., Characterising and tracking deterioration patterns of fresh-cut fruit using principal component analysis - Part I, Posthavest Biol. Technol. 100 (2015) 73-80.

Cite this article as: Giancarlo Barbieri, Emma Colonna, Youssef Rouphael, Stefania De Pascale. Effect of the farming system and postharvest frozen storage on quality attributes of two strawberry cultivars. Fruits 70 (2015) 351-360. 